\title{
EARLY COMPLETE SURGICAL TREATMENT OF A PATIENT AFTER MULTIPLE TRAUMA USING INTRAMEDULLARY NAIL AND LCP SYSTEM FROM MEDGAL COMPANY
}

\section{WCZESNE KOMPLEKSOWE LECZENIE PACJENTA PO URAZIE WIELOMIEJSCOWYM Z UŻYCIEM GWOŹDZIA ŚRÓDSZPIKOWEGO I SYSTEMU LCP FIRMY MEDGAL}

\author{
Jan Biziel University Hospital No. 2, Bydgoszcz, Poland
}

Department of Orthopaedic and Traumatology with Center of Complex Treatment of Sports Injuries

\section{S u m m a r y}

The study presents a case of a 44-year old patient admitted to the Department of Orthopaedics as an emergency to treat a multiple fractures of lower limbs.
Successful, several-stages surgical treatment and rehabilitation was performed providing very satisfactory result.

A case shows how important is the individual approach to the patient after multiple trauma.

\section{Streszczenie}

W pracy przedstawiono przypadek 44-letniego pacjenta przyjętego do Kliniki Ortopedii w trybie nagłym w celu leczenia operacyjnego wielu złamań kończyn dolnych. Przeprowadzono udane kilku -stopniowe leczenie operacyjne i rehabilitacja uzyskując bardzo zadowalający wynik . Przypadek pokazuje, jak ważne jest indywidualne podejście do pacjenta po urazie wielomiejscowym.

Key words: multiple trauma, multiple injury, straight intramedullary nail, fracture, locking compression plate (LCP)

Stowa kluczowe: uraz wielomiejscowy, uraz wielonarządowy, prosty gwoźdź śródszpikowy, złamanie, blokowana płytka kompresyjna

\section{MULTIPLE TRAUMA}

This trauma is found if injuries occur in at least two topographically different parts of the body (e.g. fracture of the humerus and the femur).

\section{MULTIPLE SYSTEM INJURY ("POLYTRAUMA")}

- Includes several systems or organs (e.g. the spine fracture with paresis and chest and abdominal injuries).
- Causes damage to at least two areas of the body to such an extent that each of them requires specialist treatment and can be life-threatening.

- Is defined as the trauma of severity of more than 18 points on an ISS (Injury Severity Score) scale with associated cardiovascular disorders (shock), coagulopathy, the respiratory and multiple organ failure.

- Injuries caused by high-energy trauma are the third leading cause of death in the general population and the first in the age group between 18 and 44 years of age! 
- Multi-organ injuries are related to long-term and expensive treatment and also with considerable financial expenditure for rehabilitation, pensions, sickness benefits and compensation.

\section{ORDER OF PROCEEDING IN CASE OF MULTIPLE INJURY}

- Directly life-threatening injuries.

- Indirectly life-threatening injuries.

- Directly limb-threatening trauma.

- Indirectly limb-threatening trauma.

Injuries require reconstructive surgery.

\section{Accident \\ 2. First Aid}

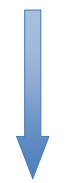

\section{Hospital (emergency department)}

\section{3. transport} (paramedic/doctor)

\section{Operating room, intensive care unit (specialist treatment)}

Fig. 1. Diagram for the time-factors in "golden-hour"

44-years old patient, the sufferer of a car crash, was forwarded to the Emergency Department by an ambulance team with life-threatening multiple injuries.

After stabilization of general patient's condition and after preliminary diagnostics (CT polytrauma and abdominal USG) he was admitted to the Department of Orthopaedics.

An additional studies showed: segmental fractures of the right femur (subtrochanteric fracture of proximal femur and multifragmentary complete articular fracture of distal femur), Schatzker type II fracture of the right tibial lateral plateau with pericapsular lateral meniscus tear, fracture of the left foot, ribs fractures on the right side, fracture of the posterolateral wall of the right maxillary sinus and laceration wound of the right hand with index finger extensor tendon injury.

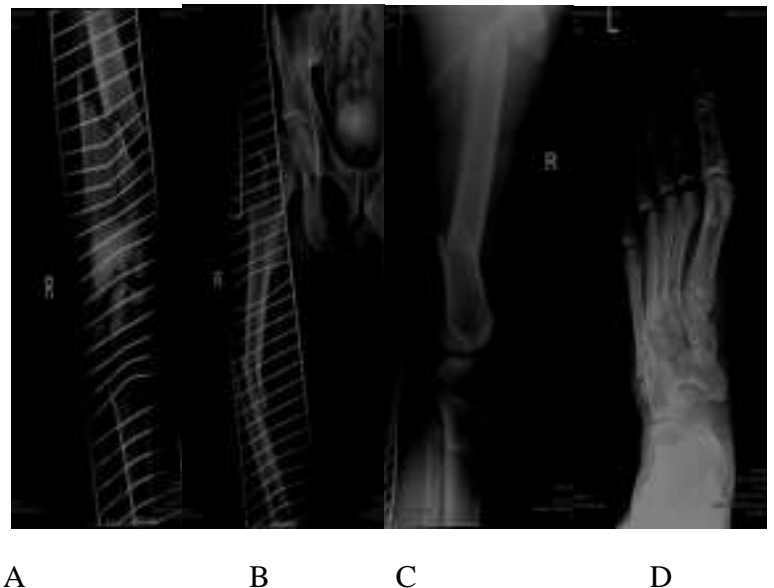

Fig. 2. A-D. X-rays taken at the day of an accident show multifragmentary and multilevel fractures of the femur, fracture of the proximal tibia and fractures of the toes I-III and metatarsals and tuberosity of the 5th metatarsal

After stabilization of general patient's condition and after clinical consultations (neurosurgical, surgical, ophthalmological, otolaryngological and anaesthetic) in the first stage a surgical repair of injured tendon of extensor of the right index finger was performed. In the next stage open reduction of the distal femur fracture with internal fixation with three HCS compressing screws and also closed reduction segmented complex fracture of the femoral shaft with antegrade nailing were performed. In the final stage, open reduction of the Schatzker II tibial plateau fracture and internal fixation using a lag screw and anatomical locking compression plate from Medgal company were undertaken with repair of lateral meniscus.

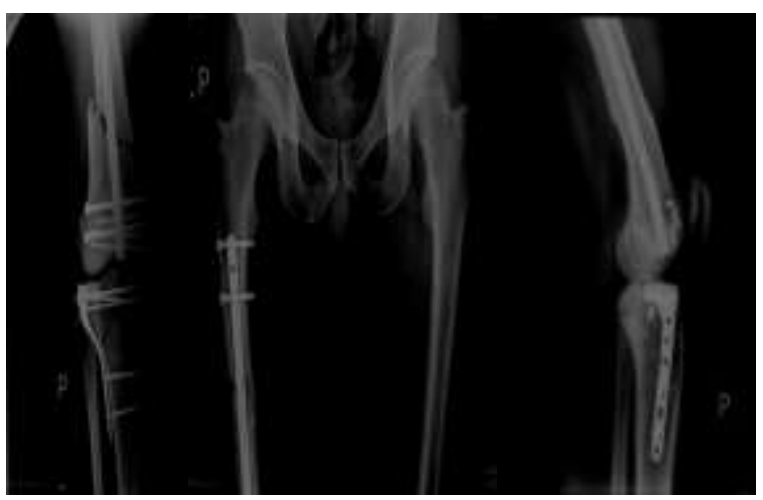

A

B

C

Fig. 3. A-C. Post-operative X-rays show proper stabilization of fractures without signs of destabilization of the implants 
During hospitalization general and local patient's condition was gradually improved. After implementation of the rehabilitation treatment, the patient was transferred to the Orthopaedic Department of the Polish Navy Hospital in Gdańsk, where he lives.

Patient is under orthopaedic care in Gdańsk. One year after the surgery the X-rays of the lower limbs was taken from a standing position.

Bone union was achieved without distortions of the limb axis and its dysfunction and with the full range of motion in the hip and the knee.

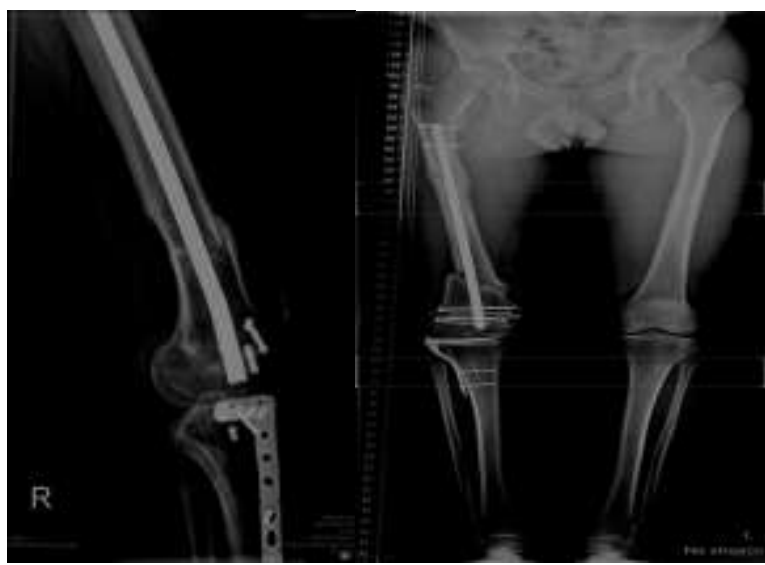

A

B

Fig. 4. A-B. X-rays of the lower limbs and right knee one year after surgery show bone union with proper limb alignment without signs of destabilization of the implants

\section{CONCLUSIONS}

Early fixation of long bone fractures in multiple trauma become the gold standard in most trauma centers in the world as well as in Poland, an example of which is our Department. These patients should be treated with extreme caution and full time care with monitoring vital signs.

\section{REFERENCES}

1. What's New in Orthopaedic Trauma William M. Ricci, MD; Michael Gardner, MD; Mark Jo, MD; Christopher McAndrew, MD. J Bone Joint Surg Am, 2012 Aug 15;94(16):1525-1535.

2. High-Energy Skeletal Trauma in the Elderly. Julie A. Switzer, MD; Steven R. Gammon, MD. J Bone Joint Surg Am, 2012 Dec 05;94(23):2195-2204.

3. Lack of Benefit of Physical Therapy on Function Following Supracondylar Humeral FractureA Randomized Controlled Trial. Gregory A. Schmale, MD;
Suzan Mazor, MD; Laina D. Mercer, MS; Viviana Bompadre, PhD. J Bone Joint Surg Am, 2014 Jun 04;96(11):944-950.

4. Femoral Intramedullary Nailing: Comparison of Fracture-Table and Manual TractionA Prospective, Randomized Study. David J.G. Stephen, MD, BSc, FRCS(C); Hans J. Kreder, MD, MPH(C), FRCS(C); Emil H. Schemitsch, MD, FRCS(C); Lisa B. Conlan ; Lisa Wild, RN; Michael D. McKee, MD, FRCS(C). J Bone Joint Surg Am, 2002 Sep;84(9):1514-1521.

5. Surgical Timing of Treating Injured Extremities. Brett D. Crist, MD; Tania Ferguson, MD; Yvonne M. Murtha, MD; Mark A. Lee, MD. J Bone Joint Surg Am, 2012 Aug 15;94(16):1514-1524.

6. Osteonecrosis of the Femoral Head After Retrograde Intramedullary Nailing of a Femoral Shaft Fracture in an AdolescentA Case Report. Darren A. Frank, MD; Robert A. Gallo, MD; Gregory T. Altman, MD; Daniel T. Altman, MD. J Bone Joint Surg Am, 2005 Sep;87(9):2080-2085.

7. The Effect of a Venous Filter on the Embolic Load During Medullary Canal Pressurization: A Canine Study. K. Mohanty, MBBS, FRCS, FRCS(Orth); J.N. Powell, MD, FRCSC; D. Musso, MD; M. Traboulsi, MD, $\mathrm{FRCP}(\mathrm{C})$; I. Belenkie, MD, FRCP(C); J.B.M. Mullen, MD, FRCP(C); J.V. Tyberg, MD, PhD. J Bone Joint Surg Am, 2005 Jun;87(6):1332-1337.

8. Controversies in Intramedullary Nailing of Femoral Shaft Fractures. Philip Wolinsky, MD; Nirmal Tejwani, MD; Jeffrey H. Richmond, MD; Kenneth J. Koval, MD; Kenneth Egol, MD; David J.G. Stephen, MD, FRCS(C). J Bone Joint Surg Am, 2001 Sep;83(9):1404-1415.

9. Intramedullary nailing of open fractures of the femoral shaft. R J Brumback ; P S Ellison Jr; A Poka ; R Lakatos ; G H Bathon ; A R Burgess. J Bone Joint Surg Am, 1999 Oct;71(9):1324-1331.

10. The management of fractures in the patient with multiple trauma. L Bone ; R Bucholz. J Bone Joint Surg Am, 1986 Jul;68(6):945-949.

11. Failure of LCP Condylar Plate Fixation in the Distal Part of the Femur. Eric E. Johnson, MD. J Bone Joint Surg Am, 2006 Nov;88(11):2539-2540.

12. Timing of Femoral Fracture Stabilization. Adam J. Starr, MD; Vernon T. Tolo, MD. J Bone Joint Surg Am, 2001 Feb;83(2):293-293.

13. Fixation of Type-C Tibial Plafond Fractures. H.L. Nag, MS. J Bone Joint Surg Am, 2004 Feb;86(2):431-432.

14. Femoral Fracture Fixation in Developing Countries: An Evaluation of the Surgical Implant Generation Network (SIGN) Intramedullary Nail. Patrick Sekimpi, MD; Kanu Okike, MD, MPH; Lewis Zirkle, MD; Andrew Jawa, MD. J Bone Joint Surg Am, 2011 Oct 05;93(19):18111818.

15. Choice of Initial or Definitive Stabilization of Femoral Shaft Fractures Was Affected by Patient Clinical Status. J Bone Joint Surg Am, 2008 May 01;90(5):1173-1173.

16. Rate of and Risk Factors for Acute Inpatient Mortality After Orthopaedic Surgery. Timothy Bhattacharyya, MD; 
Richard Iorio, MD; William L. Healy, MD. J Bone Joint Surg Am, 2002 Apr;84(4):562-572.

17. A Functional Below-the-Knee Brace for Tibial Fractures: A Report on Its Use in One Hundred and Thirty-Five Cases. Augusto Sarmiento, MD. J Bone Joint Surg Am, 2007 Sep;89(2 suppl 2):157-169.

18. Results of Polyaxial Locked-Plate Fixation of Periarticular Fractures of the Knee. George Haidukewych, MD; Stephen A. Sems, MD; David Huebner, MD; Daniel Horwitz, MD; Bruce Levy, MD. J Bone Joint Surg Am, 2007 Mar;89(3):614-620.

19. Surgical Techniques for Complex Proximal Tibial Fractures. Jason A. Lowe, MD; Nirmal Tejwani, MD; Brad Yoo, MD; Philip Wolinsky, MD. J Bone Joint Surg Am, 2011 Aug 17;93(16):1548-1559.
20. Avoiding Complications in the Care of Fractures of the Tibia. Lisa K. Cannada, MD; Jeffrey O. Anglen, MD; Michael T. Archdeacon, MD, MSE; Dolfi Herscovici Jr., DO; Robert F. Ostrum, MD.

Sources of funding: not funded by any source.

Acknowledgments: many thanks for the coordinator of my Department and for the Medgal company.

Address for correspondence:

Marcin Weiss

ul. Pestalozziego 2/68

85-095 Bydgoszcz

Received: 3.12.2015

Accepted for publication: 23.03.2016 